\title{
アジア会議の Social Programme について*
}

森谷賢村上健

生活排水, 乙尿の処理, 処分と管理に関する第 1 回 アジア会議は，9月30日から10月4日までの間開催さ れ，9月30日には参加者を歓迎する趣旨で Welcome party が，10月 2 日には日本水質励濁研究協会長(合田 国立公害研究所水質土壤環境部長）の主催によるレセ プションがSocial programme として開催された。な 扣, 両者とも会場は建築会館のホールに打いて行われ た。

Welcome party の司会はプログラム委員の 1 人と して若輩ながら森谷が務めさせてもららことになり， 松本 (東北大学教授) 組織委員長の歓迎の挨拶, 金光 (日本環境整備教育センタ一理事長) 組織委員の乾杯の 辞により午後 6 時から始められた。顔見知りの日本の 研究者との再会を喜ぶ外国からの参加者, 会議が盛会 であろらことを主催関係者に語る人々，今日まで準備 に追われ一息ついている人々, 明日からの本番に備光 て念入りに打ち合わせをする人々，ホールの中では ビールや水割りを片手に 8 時近くまで談笑が続いた。

一方, 日本水質污濁研究協会長のレセプションは, 会長の招待者である環境庁, 建設省, 厚生省の局長, 課長, 各種の公益法人の理事長, 日本水質污濁研究協

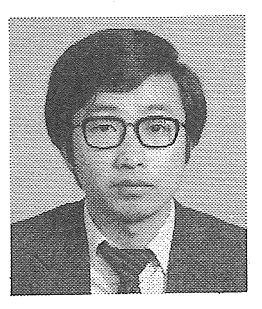

Masaru Moriya

昭和 52 年 環境庁大気保全局

54 年 同庁企画調整局

56 年 同庁大気保全局

59 年 同庁水質保全局水質管理課

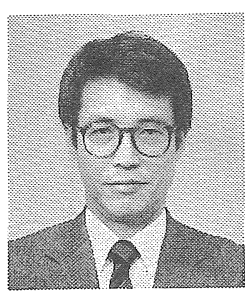

Ken Murakami

昭和 38 年 建設省土木研究所

59 年 日本下水道事業団計画上席

調査役

工学博士

〔趣 味〕探偵小説
会の名誉会員等を含め, Welcome party を凌ぐ参加者 を得て立食形式で行われた。合田会長, 松本組織委員 長がホールの入ロで出席者を出迎えた後, 真柄（国立 公衆衛生院衛生工学部長) プログラム委員の司会のも とに，合田会長による会議の持つ意義, 関係方面の協 力に対する感謝等を内容とした挨拶が行われ, さらに 久保 (日本下水道協会理事長) 組織委員による乾杯の 音頭により会食が始められた。口頭発表やポスター発 表が丸 2 日間既に行われたこともあり，ホールのあち こちでなごやかに会話が弾み，料理をほおばりグラス を傾けながら互いの挨拶，質問，議論等が，時間の経 過を忘れて進められた。

Welcome party とレセプションの出席者のやりと りの多くを紹介できないことを扣許し願いたいと思い ます。日頃，行政を担当していることもあり，森谷が レセプション等の間に話のやりとりができたことと言 えば, 中国環境科学学会の副秘書長の Dr. Zhu さん, 同国の国家環境保護局の国際担当の Mrs. Liuさんか ら中国に拈ける環境対策の現状や，香港政府の環境保 護庁の Mr. Choi さんから廃棄物の処理や近海の水質 污濁の悩夕をお聞きしたり，南米や東南アジアからの JICA 環境技術ュースの参加者や口頭発表のChairmanを一緒に務めたDr.C. Polprasert(Asian Institute of Technology, Thailand)さんに日本の環境政策，特 に環境庁の役割等を説明する程度でした。

また，会議の発表が終わった翌日の10月 4 日には， 海外からの参加者を対象とした 1 日見学旅行を行いま した。佐倉市を中心とする印旙衛生施設管理組合のし 尿処理場，東金市の下水処理場掞よび東京都の葛西処 理場の 3 力所の他，息抜さも兼水て佐倉市にある国立 歴史民俗博物館を見学しました。16力国28名の方々の 参加を得ましたが, 見学先で非常に丁寧な説明を受け, 皆様に満足いただけたようです。

* About Social Programme in IAWPRC 1st Asian Conference, 昭和 60 年 12 月 25 日受理 